\title{
Article \\ Antibacterial, Antibiofilm and Anti-Virulence Activity of Biactive Fractions from Mucus Secretion of Giant African Snail Achatina fulica against Staphylococcus aureus Strains
}

\author{
Libardo Suárez ${ }^{1,2}$, Andrés Pereira ${ }^{2}$, William Hidalgo ${ }^{1, *}$ (1) and Nelson Uribe ${ }^{2}$ \\ 1 Grupo de Investigación en Bioquímica y Microbiología (GIBIM), Escuela de Química, Universidad Industrial \\ de Santander, Edificio Camilo Torres 202, Bucaramanga 680002, Colombia; libardo2178128@correo.uis.edu.co \\ 2 Grupo de Inmunología y Epidemiología Molecular (GIEM), Escuela de Microbiología, Facultad de Salud, \\ Universidad Industrial de Santander, Bucaramanga 680002, Colombia; \\ andres.pereira@correo.uis.edu.co (A.P.); nelurdel@uis.edu.co (N.U.) \\ * Correspondence: whidalgo@uis.edu.co; Tel.: +57-(7)-634-40-00 (ext. 2025)
}

check for updates

Citation: Suárez, L.; Pereira, A.; Hidalgo, W.; Uribe, N. Antibacterial, Antibiofilm and Anti-Virulence Activity of Biactive Fractions from Mucus Secretion of Giant African Snail Achatina fulica against Staphylococcus aureus Strains. Antibiotics 2021, 10, 1548. https:// doi.org/10.3390/antibiotics10121548

Academic Editor: Alessia Catalano

Received: 19 November 2021 Accepted: 14 December 2021 Published: 17 December 2021

Publisher's Note: MDPI stays neutral with regard to jurisdictional claims in published maps and institutional affiliations.

Copyright: (c) 2021 by the authors. Licensee MDPI, Basel, Switzerland. This article is an open access article distributed under the terms and conditions of the Creative Commons Attribution (CC BY) license (https:/ / creativecommons.org/licenses/by/ $4.0 /)$.

\begin{abstract}
Staphylococcus aureus is an important etiological agent that causes skin infections, and has the propensity to form biofilms, leading to significant mortality and morbidity in patients with wounds. Mucus secretion from the Giant African snail Achatina fulica is a potential source of biologically active substances that might be an important source for new drugs to treat resistant and biofilm-forming bacteria such as $S$. aureus. This study evaluated the effect of semi-purified fractions from the mucus secretion of A. fulica on the growth, biofilm formation and virulence factors of S. aureus. Two fractions: FMA30 (Mw >30 kDa) and FME30 (Mw 30-10 kDa) exhibited antimicrobial activity against $S$. aureus with a $\mathrm{MIC}_{50}$ of 25 and $125 \mu \mathrm{g} / \mathrm{mL}$, respectively. An inhibition of biofilm formation higher than $80 \%$ was observed at $9 \mu \mathrm{g} / \mathrm{mL}$ with FMA30 and $120 \mu \mathrm{g} / \mathrm{mL}$ with FME30. Furthermore, inhibition of hemolytic and protease activity was determined using a concentration of $\mathrm{MIC}_{20}$, and FME30 showed a strong inhibitory effect in the formation of clots. We report for the first time the effect of semi-purified fractions of mucus secretion of A. fulica on biofilm formation and activity of virulence factors such as $\alpha$-hemolysin, coagulase and proteases produced by S. aureus strains.
\end{abstract}

Keywords: Achatina fulica; biofilm; antibacterial activity; Staphylococcus aureus

\section{Introduction}

Staphylococcus aureus is an opportunistic pathogen and a leading cause of skin infections, as well as an important cause of pneumonia and bacteremia in both healthcare and community settings [1]. In addition, S. aureus has the propensity to form biofilms and attachment to medical implants and host tissue, playing an important role in the persistence of chronic infections [2].

The first methicillin-resistant strain of S. aureus was reported in 1960 and developed over time resistance to different antibiotics such as linezolid, daptomycin and glycopeptides [3]. For this reason, in 2017 the World Health Organization (WHO) included this microorganism in the "Global priority list of antibiotic-resistant bacteria to guide research, discovery, and development of new antibiotics" [4].

Research into new natural compounds with antimicrobial activity or that inhibit biofilm formation is a priority in the fight against antimicrobial resistance [4,5].

Phylum Mollusca, among other invertebrates, are a large reservoir for pharmacologically active compounds present in hemolymph and mucus secretions [6-8]. Mucus secretion from the Giant African snail Achatina fulica is a potential source of biologically active substances that might lead to the discovery of new drugs to treat resistant bacteria such as MRSA [9]. Phylum Mollusca, among other invertebrates, are a large reservoir for 
pharmacologically active compounds present in hemolymph and mucus secretions $[6,7]$. Mucus secretion from Giant African snail Achatina fulica is a potential source of biologically active substances that might lead to the discovery of new drugs to treat resistant bacteria such as MRSA [9].

A. fulica is a gastropod native to eastern Africa, reported in more than 60 countries on five continents, and included in the 100 of the World's Worst Invasive Alien Species, due to the impact on agriculture, ecosystems, human health and economy [10]. Despite of some studies on the mucus of this snail that have shown different biological activities such as inhibition of microbial growth, inhibition of inflammatory processes, and healing properties, there is still little information available about antimicrobial compounds and biofilm formation inhibitors from $A$. fulica and terrestrial gastropods in general [11-13].

The antibacterial effect of the mucus of $A$. fulica seems to be related to the presence of proteins and antimicrobial peptides (AMPs). Nevertheless, aside from the L-amino acid oxidase Achacin (59 kDa) or the cysteine-rich AMP mytimacin-AF (9.7 kDa), few antimicrobial compounds have been fully identified and characterized [7,12].

Hemocyanin is one of the most important proteins present in the hemolymph of crustaceans, arachnids and mollusks that is responsible for the transport of oxygen. Its function is equivalent to that of hemoglobin in humans. So far, hemocyanin has only been found in two phyla of the animal kingdom: in mollusks and in arthropods. In mollusks it has been found in all cephalopods, and in arthropods in all decapods [14,15]. However, in these two phyla the distribution of hemocyanin is erratic, for example, in the snail of the genus Helix it is found in large quantities, but in the freshwater species Planorbis, no hemocyanin has been found. Likewise, hemocyanin has been found in certain types of scorpions and spiders $[15,16]$.

The interest of hemocyanin as a bioactive molecule against pathogenic microorganisms is relatively recent $[17,18]$. In the same way, the hemocyanin studied has been mainly from some species of shrimp, crabs and arachnids. For example, rondonin $(1.2 \mathrm{kDa})$ is a peptide with antifungal activity against Candida albicans that inhibits its growth at a concentration of $67 \mathrm{mM}$. The rondonin sequence (IIIQYEGHKH) shows identity with the C-terminal fragment of the " $\mathrm{d}$ " subunit of hemocyanin from the Eurypelma californicum tarantula [16].

On the other hand, although in 2018 Ishwaryam et al. reported the antibiofilm activity of $78 \mathrm{kDa}$ subunit of crustacean hemocyanin [19], the information on the antibiofilm and anti-virulence activity of terrestrial mollusks hemocyanin is still very scarce. Therefore, we consider that the study of not only purified subunits, but fractions with peptides derived from hemocyanin from other species of mollusks has interest and brings valuable information for novel studies in this area.

Here, we report the antimicrobial activity of fractions of A. fulica mucus against S. aureus strains and, for the first time, described is the effect of semi-purified fractions of mucus secretion on biofilm formation and anti-virulence activity on factors such as $\alpha$-hemolysin, coagulase, and proteases produced by S. aureus.

\section{Results}

\subsection{Purification and Characterization of Fractions from Mucus of Achatina fulica}

The purified crude mucus extract separated in three semi-purified fractions named FMA30 (Mw $>30 \mathrm{kDa})$, FME30 (Mw 30-10 kDa) and FME10 (Mw $<10 \mathrm{kDa})$ were obtained using ultra-centrifugal filters with pore size of $30 \mathrm{kDa}$ and $10 \mathrm{kDa}$, although in the fraction less than $10 \mathrm{kDa}$, no bands on the SDS-PAGE gel were observed. For the fraction greater than $30 \mathrm{kDa}$, the same bands of approximately $20 \mathrm{kDa}, 30 \mathrm{kDa}, 40 \mathrm{kDa}, 60 \mathrm{kDa}$ and $80 \mathrm{kDa}$ were constantly obtained (Figure 1). 


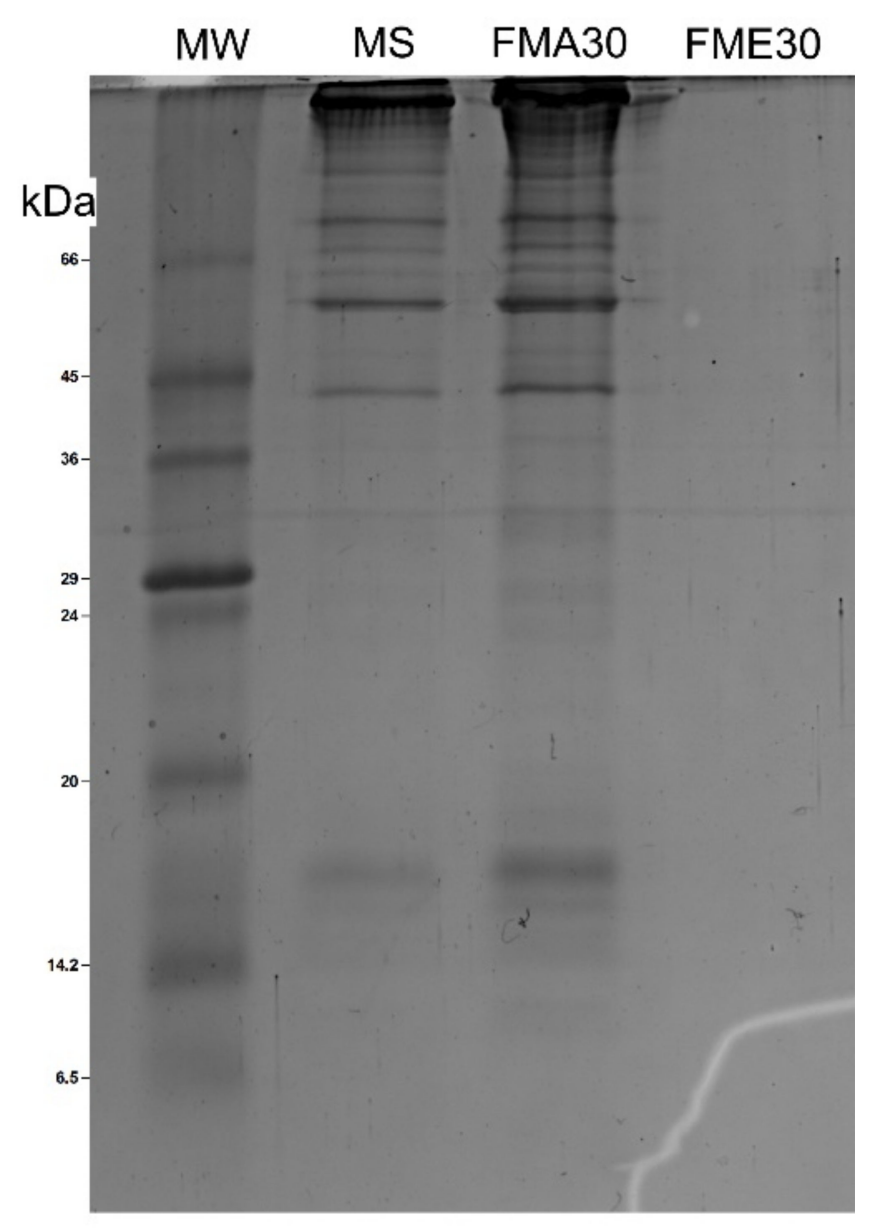

Figure 1. SDS-PAGE of separated fractions of mucus secretion of A. fulica. MW (molecular weight marker), MS (mucus secretion).

Mass analysis revealed that the bands of approximately $20 \mathrm{kDa}, 40 \mathrm{kDa}, 60 \mathrm{kDa}$ and $80 \mathrm{kDa}$ were composed of peptides that are part of the hemocyanin protein. A total of 20 (Table 1) peptides were identified in FMA30 that support the presence of hemocyanin in the mucus secretion of $A$. fulica. Since the A. fulica hemocyanin sequence is not available in UniProt/SwissProt database for mollusks, the alignment of the peptides using the BLASTp tool confirmed their identity with hemocyanin from land snails C. asperum, H. pomatia, $H$ locrum, the freshwater snail L. stagnalis and the marine gastropod Aplysia californica.

Table 1. Peptides that are part of hemocyanin identified in fraction FMA30 of the mucus secretion of $A$. fulica.

\begin{tabular}{|c|c|c|c|}
\hline$\#$ & Sequence & Origin & ID \\
\hline 1 & IYSRPADTFDYRN & Hemocyanin alphaD OS $=$ Cornu aspersum $\mathrm{OX}=6535 \mathrm{PE}=2 \mathrm{SV}=1$ & A0A3G2VFQ5 \\
\hline 2 & RLLTVQAENALRKH & Hemocyanin alphaD OS $=$ Cornu aspersum $\mathrm{OX}=6535 \mathrm{PE}=2 \mathrm{SV}=1$ & A0A3G2VFQ5 \\
\hline 3 & RKPLQPFQDKT & Hemocyanin alphaD OS $=$ Cornu aspersum $\mathrm{OX}=6535 \mathrm{PE}=2 \mathrm{SV}=1$ & A0A3G2VFQ5 \\
\hline 4 & RLHGIGVSĀDVRV & Hemocyanin alphaD OS $=$ Cornu aspersum $\mathrm{OX}=6535 \mathrm{PE}=2 \mathrm{SV}=1$ & A0A3G2VFQ5 \\
\hline 5 & REMPWAYERL & Hemocyanin alphaD OS $=$ Cornu aspersum $\mathrm{OX}=6535 \mathrm{PE}=2 \mathrm{SV}=1$ & A0A3G2VFQ5 \\
\hline 6 & RKPLQPFQDKK & Hemocyanin alphaD OS $=$ Helix pomatia $\mathrm{OX}=6536 \mathrm{PE}=2 \mathrm{SV}=1$ & A0A3G2VHR9 \\
\hline 7 & RYSRPADTFDYRN & Hemocyanin $1 \mathrm{OS}=$ Lymnaea stagnalis $\mathrm{OX}=6523 \mathrm{PE}=2 \mathrm{SV}=1$ & A0A3G2VM51 \\
\hline 8 & RAIDAFDYDRL & Hemocyanin $1 \mathrm{OS}=$ Lymnaea stagnalis $\mathrm{OX}=6523 \mathrm{PE}=2 \mathrm{SV}=1$ & A0A3G2VM51 \\
\hline 9 & KYDVTNVFNKL & Hemocyanin $1 \mathrm{OS}=$ Lymnaea stagnalis $\mathrm{OX}=6523 \mathrm{PE}=2 \mathrm{SV}=1$ & A0A3G2VM51 \\
\hline 10 & KEMPWAYERI & Hemocyanin $1 \mathrm{OS}=$ Lymnaea stagnalis $\mathrm{OX}=6523 \mathrm{PE}=2 \mathrm{SV}=1$ & A0A3G2VM51 \\
\hline 11 & SGRVEFEHVDTERD & $\begin{array}{l}\text { Hemocyanin alphaN-subunit (Fragment) OS = Helix lucorum } \\
\qquad \mathrm{OX}=31,229 \mathrm{PE}=2 \mathrm{SV}=1\end{array}$ & G3FPE7 \\
\hline
\end{tabular}


Table 1. Cont.

\begin{tabular}{|c|c|c|c|}
\hline \# & Sequence & Origin & ID \\
\hline 12 & RYDVTNVFNKL & $\begin{array}{l}\text { Hemocyanin alphaN-subunit (Fragment) OS }=\text { Helix lucorum } \\
\qquad \mathrm{OX}=31,229 \mathrm{PE}=2 \mathrm{SV}=1\end{array}$ & G3FPE7 \\
\hline 13 & RLYVVQLEQALKEKG & Hemocyanin $1 \mathrm{OS}=$ Lymnaea stagnalis $\mathrm{OX}=6523 \mathrm{PE}=2 \mathrm{SV}=1$ & A0A3G2VM51 \\
\hline 14 & DPLFLLHHSNVDRQ & Hemocyanin $1 \mathrm{OS}=$ Lymnaea stagnalis $\mathrm{OX}=6523 \mathrm{PE}=2 \mathrm{SV}=1$ & A0A3G2VM51 \\
\hline 15 & KYSRPIDTFDYRN & Hemocyanin alphaD OS $=$ Cornu aspersum $\mathrm{OX}=6535 \mathrm{PE}=2 \mathrm{SV}=1$ & A0A3G2VHN3 \\
\hline 16 & RLLTVQAENALRN & Hemocyanin alphaD OS $=$ Cornu aspersum $\mathrm{OX}=6535 \mathrm{PE}=2 \mathrm{SV}=1$ & A0A3G2VHN3 \\
\hline 17 & RIYIVVEDH & Hemocyanin alphaD OS $=$ Cornu aspersum $\mathrm{OX}=6535 \mathrm{PE}=2 \mathrm{SV}=1$ & A0A3G2VHN3 \\
\hline 18 & RAIDAFDYDRF & Hemocyanin $1 \mathrm{OS}=$ Aplysia californica $\mathrm{OX}=6500 \mathrm{PE}=2 \mathrm{SV}=1$ & A0A3G9M8B7 \\
\hline 19 & RLLTVQAENALRR & Hemocyanin $1 \mathrm{OS}=$ Aplysia californica $\mathrm{OX}=6500 \mathrm{PE}=2 \mathrm{SV}=1$ & A0A3G9M8B7 \\
\hline 20 & KVAGEDAVTTRD & Hemocyanin alphaD OS $=$ Cornu aspersum $\mathrm{OX}=6535 \mathrm{PE}=2 \mathrm{SV}=1$ & A0A3G2VFQ5 \\
\hline
\end{tabular}

The mass analysis of FME30 showed two peptides that did not match entries in the UniProt/SwissProt database for mollusks and AMPs.

\subsection{In Vitro Determination of MIC}

The antimicrobial activity of fractions against Staphylococcus strains were determined by measuring MIC $_{50}$ (Table 2). The fraction FMA30 exhibited the best antimicrobial activity against S. aureus CMPUJ 015 and S. aureus ATCC 29213 with a $\mathrm{MIC}_{50}$ of 25 and $125 \mu \mathrm{g} / \mathrm{mL}$, respectively. Additionally, the sub-inhibitory MICs (Table 2) were determined, as they were necessary for further bioassays. Additionally, FME10 was evaluated (a fraction obtained with a filter of $10 \mathrm{kDa}$ ) but it did not exhibit biological activity (Figure S1).

Table 2. Minimum inhibitory concentration $50\left(\mathrm{MIC}_{50}, \mu \mathrm{g} / \mathrm{mL}\right)$ and sub-inhibitory concentrations $\left(\mathrm{MIC}_{20}, \mu \mathrm{g} / \mathrm{mL}\right)$ of the two fractions on S. aureus CMPUJ 015 and S. aureus ATCC 29213.

\begin{tabular}{ccccc}
\hline \multirow{2}{*}{ Mucus Fraction } & \multicolumn{4}{c}{ Antimicrobial Activity } \\
\cline { 2 - 5 } & \multicolumn{3}{c}{ S. aureus CMPUJ $\mathbf{0 1 5}$} & \multicolumn{1}{c}{ S. aureus ATCC 29213 } \\
\hline & MIC $_{20}$ & MIC $_{50}$ & MIC $_{20}$ & MIC $_{50}$ \\
FMA30 & 10 & 25 & 12 & 125 \\
FME30 & 120 & 500 & 250 & 750 \\
\hline
\end{tabular}

\subsection{In Vitro Inhibition of Biofilm Formation}

Inhibition of biofilm was performed for the two fractions tested at sub-inhibitory concentrations. The results were expressed as the percentage of inhibition (Figure 2). An inhibition of biofilm formation higher than $80 \%$ was observed at $9 \mu \mathrm{g} / \mathrm{mL}$ and $120 \mu \mathrm{g} / \mathrm{mL}$ with fractions FMA30 and FME30, respectively.
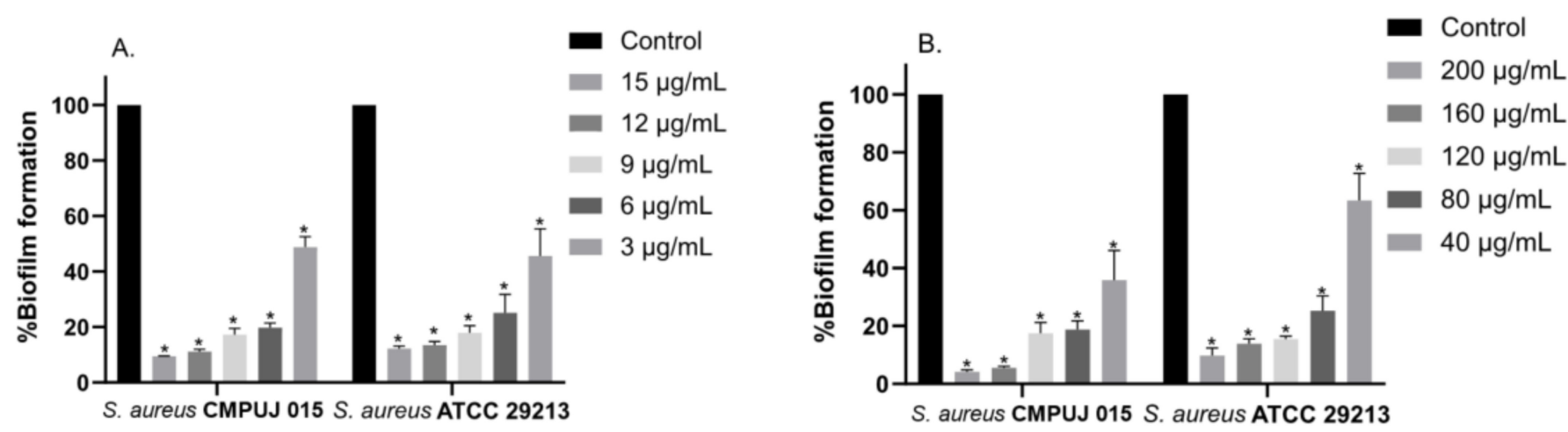

Figure 2. Antibiofilm effect on S. aureus CMPUJ 015 and S. aureus ATCC 29213 by (A) FMA30, (B) FME30. Data are represented as mean $\pm \mathrm{SD}$. ANOVA was used to show statistically significant differences compared to control $\left({ }^{*} p<0.001\right)$. 


\subsection{Inhibition of Virulence Factors}

An inhibition of hemolytic activity higher than $90 \%$ was observed using a concentration of $\mathrm{MIC}_{20}$ of fraction FMA30, and at the same concentration was evidenced inhibition of protease activity (Table 3). Based on the tests carried out for coagulase effect, with the FME30 fraction, there is a marked inhibition in the formation of clots when compared with the control; on the contrary, with the FMA30 fraction there was little or no inhibition (Table 4, Figure S2).

Table 3. Inhibition of hemolysin and protease production by S. aureus strains.

\begin{tabular}{ccccc}
\hline \multirow{2}{*}{ Mucus Fraction } & \multicolumn{2}{c}{ S. aureus CMPUJ 015 } & \multicolumn{2}{c}{ S. aureus ATCC 29213 } \\
\cline { 2 - 5 } & $\begin{array}{c}\text { Hemolytic Activity } \\
\text { Inhibition (\%) }\end{array}$ & $\begin{array}{c}\text { Protease Activity } \\
\text { Inhibition (\%) }\end{array}$ & $\begin{array}{c}\text { Hemolytic Activity } \\
\text { Inhibition (\%) }\end{array}$ & $\begin{array}{c}\text { Protease Activity } \\
\text { Inhibition (\%) }\end{array}$ \\
\hline FMA30 & $98.60 \pm 1.44$ & $73.55 \pm 2.08$ & $97.43 \pm 2.97$ & $<20$ \\
FME30 & $96.69 \pm 1.89$ & $80.34 \pm 3.72$ & $75.74 \pm 3.39$ & $31.46 \pm 6.15$ \\
\hline
\end{tabular}

Table 4. Inhibition of the coagulase production of S. aureus strains.

\begin{tabular}{ccc}
\hline Mucus Fraction & S. aureus CMPUJ 015 & S. aureus ATCC 29213 \\
\hline FMA30 & +++ & ++ \\
FME30 & + & + \\
\hline
\end{tabular}

$(+++)$ Total, (++) partial, (+) minimum presence of clots.

\section{Discussion}

Among the components of the mucus secretion of A. fulica are mucoproteins, peptides, uronic acids, glycosaminoglycans and allantoin; however, those directly related to antimicrobial activity appear to be peptides and proteins [9]. This is supported by studies that have identified peptides and proteins with antimicrobial activity against Gram-positive and Gram-negative bacteria, for example, the glycoprotein Achacin has antimicrobial activity against Bacillus subtilis, S. aureus, Escherichia coli and Pseudomonas aeruginosa [20,21], and the cysteine-rich peptide mytimacin- $A F$, isolated from the mucus secretion, has activity against S. aureus, Bacillus megatherium, E. coli, Bacillus pyocyaneus, B. dysenteriae, Klebsiella pneumoniae and Candida albicans, reporting for the first time, antifungal activity [12]. In addition, proteins of $50.81 \mathrm{kDa}, 15 \mathrm{kDa}$ and $11.45 \mathrm{kDa}$ have been reported biological activity against Streptococcus mutans and Aggregatibacter actinomycetemcomitans [22].

Although there are studies that demonstrate the antimicrobial properties of the mucus secretion of A. fulica, little is known about the activity on resistant bacteria. A previous study carried out by our research group determined the inhibitory action of mucus secretion against $S$. aureus CMPUJ 015 [9], which was confirmed in this work.

From the results, it is considered the mucus secretion and its fractions have a bacteriostatic effect instead of bactericidal effect on $S$. aureus strains, because an increase of the culture absorbance was observed after $24 \mathrm{~h}$ of exposure to the fractions, indicating growth of a viable cell. However, it is necessary to carry out complementary tests to determine the mechanism of action of the components of the fractions that exert antimicrobial activity.

The ability of bacteria to form biofilms is one of the main virulence factors that interferes with the activity of antibiotics and mechanisms of immune defense response. For this reason, the inhibition of biofilm formation has become very important in the search for new strategies to combat the antimicrobial resistance issues [23]. We have not found any study evaluating the effects of mucus secretion of $A$. fulica on bacterial biofilm formation. In this study, we found that fractions isolated from mucus secretion had an inhibitory effect on the biofilm formation of both $S$. aureus strains at concentrations below the $\mathrm{MIC}_{50}$. This result is very important since biofilm-forming S. aureus strains is the major cause of infection in medical implants and wounds [2]. 
Since the treatment with anti-virulence agents can be an alternative to antibiotics therapy, anti-virulence effects of the fractions of A. fulica were also assessed. In this context, $S$. aureus produces an arsenal of virulence factors, including $\alpha$-hemolysin, coagulase, and proteases, which are involved in different pathogenicity processes and biofilm formation. An inhibition of hemolytic and protease activities, using a concentration of $\mathrm{MIC}_{20}$ for both fractions, were determined (Table 2). Based on the tests carried out for coagulase effect, the FME30 fraction induced a strong inhibition on the formation of clots when compared to the control, whereas the FMA30 fraction showed a weak inhibitory effect.

To our knowledge, this is the first report of antibiofilm and anti-virulence effect of the mucus from A. fulica. Although in recent years, different studies have showed evidence of inhibition of virulence factors and biofilm formation of $S$. aureus strains, those were carried out with different compounds and natural products such as essential oils, antimicrobial peptides and nanoparticles [24-32], but not with gastropod mucus secretions.

Protein fractions, derived from the mucus secretion of $A$. fulica, are a rich source of antimicrobial, antibiofilm and anti-virulence bioactive molecules against $S$. aureus strains. The analysis with SDS-PAGE revealed the presence of proteins ranged from 20 to $80 \mathrm{kDa}$ and by mass spectrometry analysis was identified as hemocyanin-derived peptides present in FMA30.

Most of the known AMPs come from the processing of larger inactive proteins; however, some studies suggest that biologically active proteins, such as hemocyanin [18] and hemoglobin [33], can be sources of AMPs. Hemocyanin-derived peptides with antimicrobial properties have previously been reported in shrimp [34-36], crayfish [18] and spiders [16]. The bibliographic review indicates that until 2015, the first AMPs derived from hemocyanin from mollusks were registered [37].

Dolashka et al., 2016, reported the antimicrobial activity of hemocyanin subunits between 45 and $65 \mathrm{kDa}$, finding inhibitory activity against Gram-positive and Gramnegative bacteria. In our work, we report the antimicrobial, antibiofilm and anti-virulence activity of semi-purified fractions containing peptides derived from hemocyanin of the gastropod A. fulica using subMIC, which demonstrates that the effect of the fractions is involved with the metabolism involved in biofilm formation and the different virulence factors, and is not simply due to a decrease in bacterial population.

Dolashki et al., 2020, reported three potential AMPs from the mucus secretion of the land snail Cornu aspersum, whose alignment in BLAST demonstrates high homology with hemocyanins isolated from snails Helix aspersa, Helix pomatia and Helix lucorum [38]. The authors of this study report that a comparison of the alignment of the amino acid sequence of the peptides of the mucosal secretion of H. aspersa with the CAMP (Collection of Anti-Microbial Peptides) databases revealed a high identity (greater than $70 \%$ ) with known AMPs [38].

Probably proteolytic processes may have led to the appearance of these peptides in the mucus secretion. Some of the identified peptides contain high levels of glycine, leucine and proline residues, which are probably important for the stability of their antimicrobial activity.

The hemocyanin-derived peptides found in this study can be used for the in silico design of analogous peptides with antimicrobial activity [39]. Low molecular weight molecules, such as peptides, offer advantages over high molecular weight subunits, including greater ease in synthesis, ease of making modifications that improve their activity and ease of encapsulation or fixation to improve their bioavailability, among others [40].

\section{Materials and Methods}

\subsection{Mucus Collection and Sample Fractionation}

The specimens of A. fulica were collected in Floridablanca, Santander, Colombia. Snails were identified as A. fulica by morphological characteristics. Specimens with size of the shell between $5-12 \mathrm{~cm}$ were collected. The mucus secretion was obtained by direct 
stimulation on the foot of the snail with an electric current of $9 \mathrm{~V}$ at intervals of 30 to $60 \mathrm{~s}$. A pool of mucus was collected in sterile Falcon tubes $(50 \mathrm{~mL})$.

The sample was homogenized by mixing equal volume of mucus secretion and phosphate-buffered saline (PBS) containing protease inhibitors (ethylenediaminetetraacetic acid (EDTA) $2 \mathrm{mM}$, phenylmethylsulfonyl fluoride (PMSF) $1 \mathrm{mM}$, and sodium orthovanadate $1 \mathrm{mM}$ in constant agitation $(150 \mathrm{rpm})$ for $24 \mathrm{~h}$. The samples were centrifuged at $8000 \times g$ for $15 \mathrm{~min}$ at $4{ }^{\circ} \mathrm{C}$. The supernatant was precipitated with ammonium sulfate at $60 \%$ to recover proteins and peptides and remove impurities. The biological extract obtained was fractionated based on their molecular size by using ultracentrifugal filters (30 kDa and $10 \mathrm{kDa}$ ). The fractions collected, FMA30 (fraction containing proteins and peptides with molecular size more than $30 \mathrm{kDa}$ ) and FME30 (fraction containing proteins and peptides with molecular size less than $30 \mathrm{kDa}$ ), were freeze-dried and stored at $-80{ }^{\circ} \mathrm{C}$ before use.

\subsection{SDS-PAGE Electrophoresis}

In order to identify the molecular weight of the fractions obtained, SDS-PAGE electrophoresis was carried out in $14 \%$ polyacrylamide gel. In brief, the samples were mixed with Laemmli buffer $(3.55 \mathrm{~mL}$ of type I water; $1.25 \mathrm{~mL}$ of $0.5 \mathrm{M}$ Tris- $\mathrm{HCl}$ at $\mathrm{pH} 6.8 ; 2.5 \mathrm{~mL}$ of $0.5 \mathrm{M}$ Tris- $\mathrm{HCl}$ at $\mathrm{pH} 6.8 ; 2.5 \mathrm{~mL}$ of $0.5 \mathrm{M}$ Tris- $\mathrm{HCl}$ at $\mathrm{pH} 6.8 ; 2.5 \mathrm{~mL}$ glycerol; $2 \mathrm{~mL} 10 \%$ SDS and $0.2 \mathrm{mg} 0.5 \%$ bromophenol blue) in $1: 1$ proportion and heated to $95{ }^{\circ} \mathrm{C}$ for $5 \mathrm{~min}$. The

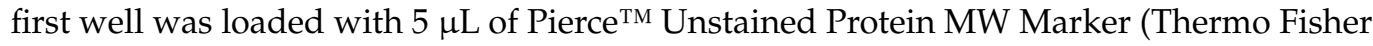
Scientific, Waltham, MA, USA) and $15 \mu \mathrm{g}$ of total protein for the sample wells. Gels were run at an initial voltage of $50 \mathrm{~V}$ for $20 \mathrm{~min}$, then, the voltage was raised to $150 \mathrm{~V}$ for $85 \mathrm{~min}$. The gel was removed and subjected to Coomassie R-250 staining for $1 \mathrm{~h}$, and washed with decolorizing solution (50\% methanol, 10\% acetic acid) until the respective visualization of the bands was achieved. The gels were scanned with a ChemiDoc ${ }^{\mathrm{TM}}$ Imaging System (Bio-Rad Laboratories, Hercules, CA, USA) and analyzed with Image Lab 6.1 software (Bio-Rad Laboratories, Hercules, CA, USA).

\subsection{Molecular Mass Analysis}

To the mass spectrometry protein identification, the SDS-PAGE protein bands were excised from gels and subjected to reduction $(10 \mathrm{mM}$ dithiothreitol), alkylation (50 $\mathrm{mM}$ iodoacetamide), with subsequent overnight in-gel digestion with sequencing grade bovine trypsin (in $25 \mathrm{mM}$ ammonium bicarbonate) using an automated workstation (Intavis, Cologne, Germany). The resulting peptides were submitted to nESI-MS/MS on a $Q$ Exactive Plus ${ }^{\circledR}$ mass spectrometer (Thermo Fisher Scientific, Waltham, MA, USA). A total of $10 \mu \mathrm{L}$ of each tryptic digest were loaded on a C18 trap column $(75 \mu \mathrm{m} \times 2 \mathrm{~cm}, 3 \mu \mathrm{m}$ particle; PepMap, Thermo), washed with $0.1 \%$ formic acid (solution A), and separated at $200 \mathrm{~nL} / \mathrm{min}$ with Easy-spray ${ }^{\circledR}$ analytical column using a nano-Easy ${ }^{\circledR} 1200$ chromatograph (3 $\mu \mathrm{m}$ particle, $15 \mathrm{~cm} \times 75 \mu \mathrm{m}$ C18, Thermo Fisher Scientific, Waltham, MA, USA). A gradient from $0.1 \%$ formic acid (solution $\mathrm{A}$ ) to $80 \%$ acetonitrile with $0.1 \%$ formic acid (solution B) was developed: 1-5\% B in $1 \mathrm{~min}, 5-26 \% \mathrm{~B}$ in $25 \mathrm{~min}, 26-79 \% \mathrm{~B}$ in $4 \mathrm{~min}$, $79-99 \% \mathrm{~B}$ in $1 \mathrm{~min}$ and $99 \% \mathrm{~B}$ in $4 \mathrm{~min}$, for a total time of $35 \mathrm{~min}$. MS spectra were acquired in positive mode at $1.9 \mathrm{kV}$, with a capillary temperature of $200{ }^{\circ} \mathrm{C}$, using 1 scan at 400-1600 m/z, maximum injection time of $100 \mathrm{msec}$, AGC target of $3 \times 106$ and orbitrap resolution of 70,000. The top 10 ions with 2-5 positive charges were fragmented with AGC target of $1 \times 105$, maximum injection time of $110 \mathrm{msec}$, resolution 17,500, loop count 10, isolation window of $1.4 \mathrm{~m} / \mathrm{z}$ and a dynamic exclusion time of $5 \mathrm{~s}$. MS/MS spectra were processed for peptide matching with protein sequences contained in the UniProt/SwissProt database for mollusks, using PEAKS $X^{\circledR}$ (Bioinformatics Solutions, Waterloo, ON, Canada). Cysteine carbamidomethylation was set as a fixed modification, while deamidation of asparagine or glutamine and methionine oxidation were set as variable modifications, allowing up to 3 missed cleavages by trypsin. Parameters for match acceptance were set to FDR $<1 \%$, and $-10 \lg P$ protein score $\geq 30$. 


\subsection{Bacterial Strains and Growth Conditions}

Staphylococcus aureus ATCC 29213 strain was purchased from the American Type Culture Collection (ATCC; Rockville, MD, USA) and Staphylococcus aureus CMPUJ 015 strain was purchased from the Coleccion Microorganisms Pontificia Universidad Javeriana, which is a certified institution belonging to the World Federation of Culture Collection; antibiotic resistance pattern data were presented in the supplementary information (Table S1). Before being used for the antimicrobial, antibiofilm and anti-virulence assays, both strains were grown in Müller Hilton broth $(\mathrm{MH})$ at $37^{\circ} \mathrm{C}$.

\subsection{Determination of Minimum Inhibitory Concentration $\left(M C_{50}\right)$}

The antimicrobial effects were evaluated by using the broth microdilution method described by CLSI-M07-A10-2015 [41] adapted for new antimicrobial compounds Cruz et al., 2014 [42]. The evaluation of the minimum inhibitory concentration at $50 \%$ of the microbial population ( $\mathrm{MIC}_{50}$ ) was determined as follows: a culture of each microorganism was grown in $\mathrm{MH}$ for $12 \mathrm{~h}$ at $37^{\circ} \mathrm{C}$ with constant agitation at $200 \mathrm{rpm}$; these were adjusted until a concentration of $1.5 \times 10^{8} \mathrm{CFU} / \mathrm{mL}$. Then, $100 \mu \mathrm{L}$ of the inoculum was mixed with $100 \mu \mathrm{L}$ of mucus fraction in microplates for final concentrations of $10,20,50,120$, 250, 500 and $1250 \mu \mathrm{g} / \mathrm{mL}$. Microplates were incubated at $37^{\circ} \mathrm{C}$ with constant agitation at $200 \mathrm{rpm}$. Microbial growth was measured using a Multiskan sky spectrophotometer (Thermo Labsystems Inc., Beverly, MA, USA) at $595 \mathrm{~nm}$ every hour for $8 \mathrm{~h}$.

\subsection{Antibiofilm Activity Assay}

The evaluation of the in vitro inhibition of biofilm formation was carried out according to the method described by Molhoek et al., 2011 [43], with some modifications. Bacterial strains were grown overnight in Tryptic Soy Broth (TSB) at $37^{\circ} \mathrm{C}$ and diluted in fresh medium (1:10). Then, $100 \mu \mathrm{L}$ of cell suspension was added to sterile 96-well flat-bottom polystyrene microplates containing sub-inhibitory concentrations (subMIC) of 3, 6, 9, 12, $15 \mu \mathrm{g} / \mathrm{mL}$ for FMA30 and 40, 80, 120, 160, $200 \mu \mathrm{g} / \mathrm{mL}$ for FME30. Microplates were incubated at $37^{\circ} \mathrm{C}$ for $24 \mathrm{~h}$ without shaking. Biofilm biomass was quantified using the crystal violet staining method. The microplates were washed three times with sterile $1 \mathrm{mM}$ PBS pH 7 to remove free-floating planktonic bacteria. Then, $200 \mu \mathrm{L}$ of $0.4 \%(w / v)$ crystal violet was added to each of the wells for $15 \mathrm{~min}$. Crystal violet excess was eliminated by three consecutive washes with sterile $1 \mathrm{mM}$ PBS pH 7; $200 \mu \mathrm{L}$ of $30 \%(v / v)$ acetic acid was added to remove the adhered dye. The content of each well was transferred to a new microplate to quantify the absorbance at $595 \mathrm{~nm}$ using a Multiskan sky spectrophotometer (Thermo Labsystems Inc., Beverly, MA, USA).

\subsection{Anti-Virulence Activity Assay}

The possible inhibitory effect of mucus fractions on virulence factors such as hemolysin, coagulase and protease were evaluated following the method reported by Lee et al., 2014 [24], with some modifications. The microorganisms were incubated in TSB for $12 \mathrm{~h}$ at $37^{\circ} \mathrm{C}$ with constant agitation at $200 \mathrm{rpm}$, the concentration was adjusted to $1.5 \times 10^{8} \mathrm{CFU} / \mathrm{mL}$ and diluted 1:100 in TSB. This suspension and $\mathrm{MIC}_{20}$ of the two fractions were added to the same proportion and incubated at $37^{\circ} \mathrm{C}$ with constant agitation for $12 \mathrm{~h}$ at $200 \mathrm{rpm}$. Finally, the supernatant was centrifuged and conserved.

Evaluation of antihemolytic effect of the mucus fractions was performed as follows: $100 \mu \mathrm{L}$ of the supernatant and $100 \mu \mathrm{L}$ of a suspension of human red blood cells (the blood samples were donated by the Hemocentro de Santander, samples were screened for infectious agents including HIV and hepatitis B and the donor signed informed consent) were added into a microplate, incubated for $1 \mathrm{~h}$ at $37^{\circ} \mathrm{C}$ under agitation at $200 \mathrm{rpm}$, and centrifuged at $4000 \mathrm{rpm}$ for $4 \mathrm{~min}$. Supernatant was transferred to another microplate for reading at $430 \mathrm{~nm}$ to determine the percentage of inhibition of hemolytic activity. Assays were performed in triplicate. 
The inhibitory effect on proteases was evaluated by adding $100 \mu \mathrm{L}$ of supernatant and $100 \mu \mathrm{L}$ of skim milk (1.25\%) to a microplate, then, incubated for $1 \mathrm{~h}$ at $37^{\circ} \mathrm{C}$ under agitation at $200 \mathrm{rpm}$, and centrifuged at $4000 \mathrm{rpm}$ for $4 \mathrm{~min}$. The supernatant was transferred to another microplate for reading at $600 \mathrm{~nm}$ to determine the percentage of inhibition of protease activity. Assays were performed in triplicate.

The evaluation of the inhibitory effect on coagulase enzyme was performed by taking $100 \mu \mathrm{L}$ of supernatant and $200 \mu \mathrm{L}$ of citrated plasma, incubated for $12 \mathrm{~h}$ at $37^{\circ} \mathrm{C}$, and then visualized for the total presence, partial presence or absence of the colt. Assays were performed in triplicate.

\subsection{Data Analysis}

Unless otherwise stated, statistical tests were carried out with SigmaPlot 12.0 (SYSTAT Software Inc., San Jose, CA, USA). All the experiments were performed by triplicates and one-way analysis of variance (ANOVA) was used to analyze the differences among the treatments. In all cases, the level of significance was 0.05 . Assumption of normality and equally of variances of data was previously tested using Shapiro-Wilk and Levene's test, respectively.

\section{Conclusions}

Staphylococcus aureus is classified by WHO as one of the most important microorganisms for the development of new pharmacological alternatives to control it. This study demonstrates for the first time that the fractions of the mucus secretion of Achatina fulica exhibited anti-virulence activity against $S$. aureus strains at sub-inhibitory concentrations.

In the present study, both fractions demonstrated antibacterial, antibiofilm and antivirulence activity against Staphylococcus aureus CMPUJ 015 and Staphylococcus aureus ATCC 29213. The fraction FMA30 demonstrated the highest antibacterial and antibiofilm activity against S. aureus ATCC 29213 and S. aureus CMPUJ 015, this is mostly due to the purification and precipitation process with ammonium sulfate, which allowed eliminating impurities and concentrating the proteins and peptides present in the secretion, demonstrating that the antimicrobial activity of mucus is related to the protein material present as mentioned by different authors. Additionally, both fractions showed a highest antihemolytic effect against the $S$. aureus strains and a highest antiprotease effect against $S$. aureus strains; in contrast, only FME30 had a high anticoagulase effect.

Further studies are needed to elucidate the mechanisms of action of the A. fulica fractions and to determine the compounds related to the biological activity evaluated. Metabolomic analyses are underway to determine the metabolic pathways affected in the bacteria when treated with these fractions, as well as the characterization of the peptides and proteins present in the secretion.

Supplementary Materials: The following are available online at https:/ / www.mdpi.com/article/ 10.3390/antibiotics10121548/s1, Figure S1: Growth kinetics assay of antimicrobial effect of FME10 against (A) S. aureus ATCC 29213 and (B) S. aureus CMPUJ 015; Figure S2: Inhibition of the coagulase production of S. aureus strains. (a) S. aureus CMPUJ 015 (b) S. aureus ATCC 29213; Table S1 antibiogram of $S$. aureus strains.

Author Contributions: Conceptualization, L.S., W.H. and N.U.; methodology, L.S., A.P. and W.H.; formal analysis, L.S., W.H., A.P. and N.U.; investigation, L.S., W.H., A.P. and N.U.; writing-original draft preparation, L.S, A.P., W.H. and N.U.; writing-review and editing L.S., A.P., W.H. and N.U.; project administration, N.U. and W.H; funding acquisition, N.U. and W.H. All authors have read and agreed to the published version of the manuscript.

Funding: This research was funded by Departamento Administrativo de Ciencia, Tecnología e Innovación (COLCIENCIAS), project number 1102-777-57410 and Universidad Industrial de Santander (Vicerrectoría de Investigación y Extension, project number 8741).

Institutional Review Board Statement: The study was conducted according to the guidelines of the Declaration of Helsinki and approved by the Institutional Ethics Committee of Universidad Industrial 
de Santander, act 12 of 19 May 2017. The $5 \mathrm{~mL}$ red blood cells tubes for the evaluation of antihemolytic effect were obtained from blood samples donated by the Hemocentro de Santander. Samples were screened for infectious agents including HIV and hepatitis B. The donor signed informed consent.

Data Availability Statement: Data are contained within the article.

Acknowledgments: The authors gratefully acknowledge the financial support from Colciencias (Colombia, Project number 1102-777-57410), Universidad Industrial de Santander (Vicerrectoría de Investigación y Extensión, project number 8741) and Grupo de Inmunología y Epidemiología Molecular (GIEM) for the financial support for this publication. We also thank Laboratorio de Proteómica, Instituto Clodomiro Picado, Universidad de Costa Rica for peptide identification analysis. Authorization for the collection of wild species specimens from biological diversity for non-commercial scientific research purposes was granted by the National Environmental Licensing Authority-ANLA (Resolutions 00422 January 2015 and 02601111 March 2016).

Conflicts of Interest: The authors declare no conflict of interest.

\section{References}

1. Turner, N.A.; Sharma-Kuinkel, B.K.; Maskarinec, S.A.; Eichenberger, E.M.; Shah, P.P.; Carugati, M.; Holland, T.L.; Fowler, V.G. Methicillin-resistant Staphylococcus aureus: An overview of basic and clinical research. Nat. Rev. Microbiol. 2019, 17, $203-218$. [CrossRef]

2. Lister, J.L.; Horswill, A.R. Staphylococcus aureus biofilms: Recent developments in biofilm dispersal. Front. Cell. Infect. Microbiol. 2014, 4, 178. [CrossRef]

3. Smith, R.A.; M'ikanatha, N.M.; Read, A.F. Antibiotic Resistance: A Primer and Call to Action. Health Commun. 2015, 30, 309-314. [CrossRef] [PubMed]

4. WHO. WHO I Global Priority List of Antibiotic-Resistant Bacteria to Guide Research, Discovery, and Development of New Antibiotics; World Health Organization: Geneva, Switzerland, 2017.

5. Galdiero, E.; Lombardi, L.; Falanga, A.; Libralato, G.; Guida, M.; Carotenuto, R. Biofilms: Novel strategies based on antimicrobial peptides. Pharmaceutics 2019, 11, 322. [CrossRef]

6. Li, H.; Parisi, M.G.; Parrinello, N.; Cammarata, M.; Roch, P. Molluscan antimicrobial peptides, a review from activity-based evidences to computer-assisted sequences. Invertebr. Surviv. J. 2011, 8, 85-97.

7. Balandin, S.V.; Ovchinnikova, T.V. Antimicrobial peptides of invertebrates. Part 1. structure, biosynthesis, and evolution. Russ. J. Bioorganic Chem. 2016, 42, 229-248. [CrossRef]

8. Summer, K.; Browne, J.; Liu, L.; Benkendorff, K. Molluscan Compounds Provide Drug Leads for the Treatment and Prevention of Respiratory Disease. Mar. Drugs 2020, 18, 570. [CrossRef] [PubMed]

9. Pereira, A.E.; Rey, A.; López, J.P.; Castro, J.P.; Uribe, N. Physicochemical characterization and antimicrobial activity of mucus of Achatina fulica. Rev. Univ. Ind. Santander. Salud 2016, 48, 188-195.

10. Courchamp, F. Alien species: Monster fern makes IUCN invader list. Nature 2013, 498, 37. [CrossRef] [PubMed]

11. Iguchi, S.M.; Aikawa, T.; Matsumoto, J.J. Antibacterial Activity of Snail Mucus Mucin. Comp. Biochem. Physiol. 1982, 72, 571-574. [CrossRef]

12. Zhong, J.; Wang, W.; Yang, X.; Yan, X.; Liu, R. A novel cysteine-rich antimicrobial peptide from the mucus of the snail of Achatina fulica. Peptides 2013, 39, 1-5. [CrossRef] [PubMed]

13. Ghosh, A.K.; Hirasawa, N.; Lee, Y.S.; Kim, Y.S.; Shin, K.H.; Ryu, N.; Ohuchi, K. Inhibition by acharan sulphate of angiogenesis in experimental inflammation models. Br. J. Pharmacol. 2010, 137, 441-448. [CrossRef] [PubMed]

14. Burmester, T. Molecular Evolution of the Arthropod Hemocyanin Superfamily. Mol. Biol. Evol. 2001, 18, 184-195. [CrossRef] [PubMed]

15. Chiumiento, I.R.; Ituarte, S.; Sun, J.; Qiu, J.W.; Heras, H.; Sebastiá, N.; Dreonid, M. Hemocyanin of the caenogastropod Pomacea canaliculata exhibits evolutionary differences among gastropod clades. PLoS ONE 2020, 15, e0228325. [CrossRef]

16. Riciluca, K.C.T.; Sayegh, R.S.R.; Melo, R.L.; Silva, P.I. Rondonin an antifungal peptide from spider (Acanthoscurria rondoniae) haemolymph. Results Immunol. 2012, 2, 66-71. [CrossRef]

17. Coates, C.J.; Nairn, J. Diverse immune functions of hemocyanins. Dev. Comp. Immunol. 2014, 45, 43-55. [CrossRef]

18. Lee, S.Y.; Lee, B.L.; Söderhäll, K. Processing of an antibacterial peptide from hemocyanin of the freshwater crayfish Pacifastacus leniusculus. J. Biol. Chem. 2003, 278, 7927-7933. [CrossRef]

19. Ishwarya, R.; Vaseeharan, B.; Jayakumar, R.; Ramasubramanian, V.; Govindarajan, M.; Alharbi, N.S.; Khaled, J.M.; Al-anbr, M.N.; Benelli, G. Bio-mining drugs from the sea: High antibiofilm properties of haemocyanin purified from the haemolymph of flower crab Portunus pelagicus (L.) (Decapoda: Portunidae). Aquaculture 2018, 489, 130-140. [CrossRef]

20. Obara, K.; Otsuka-Fuchino, H.; Sattayasai, N.; Nonomura, Y.; Tsuchiya, T.; Tamiya, T. Molecular cloning of the antibacterial protein of the giant African snail, Achatina fulica Ferussac. Eur. J. Biochem. 1992, 209, 1-6. [CrossRef]

21. Ogawa, M.; Nakamura, S.; Atsuchi, T.; Tamiya, T.; Tsuchiya, T.; Nakai, S. Macromolecular antimicrobial glycoprotein, achacin, expressed in a methylotrophic yeast Pichia pastoris. FEBS Lett. 1999, 448, 41-44. [CrossRef] 
22. Kriswandini, I.L. Antimicrobial proteins of Snail mucus (Achatina fulica) against Streptococcus mutans and Aggregatibacter actinomycetemcomitans. Dent. J. 2014, 47, 31-36.

23. Gupta, P.; Sarkar, S.; Das, B.; Bhattacharjee, S.; Tribedi, P. Biofilm, pathogenesis and prevention-A journey to break the wall: A review. Arch. Microbiol. 2016, 198, 1-15. [CrossRef]

24. Lee, K.; Lee, J.-H.; Kim, S.-I.; Cho, M.H.; Lee, J. Anti-biofilm, anti-hemolysis, and anti-virulence activities of black pepper, cananga, myrrh oils, and nerolidol against Staphylococcus aureus. Appl. Microbiol. Biotechnol. 2014, 98, 9447-9457. [CrossRef] [PubMed]

25. Kannappan, A.; Srinivasan, R.; Nivetha, A.; Annapoorani, A.; Pandian, S.K.; Ravi, A.V. Anti-virulence potential of 2-hydroxy-4methoxybenzaldehyde against methicillin-resistant Staphylococcus aureus and its clinical isolates. Appl. Microbiol. Biotechnol. 2019, 103, 6747-6758. [CrossRef]

26. Hetta, H.F.; Al-Kadmy, I.M.S.; Khazaal, S.S.; Abbas, S.; Suhail, A.; El-Mokhtar, M.A.; Ellah, N.H.A.; Ahmed, E.A.; Abd-Ellatief, R.B.; El-Masry, E.A.; et al. Antibiofilm and antivirulence potential of silver nanoparticles against multidrug-resistant Acinetobacter baumannii. Sci. Rep. 2021, 11, 10751. [CrossRef]

27. Di Somma, A.; Moretta, A.; Canè, C.; Cirillo, A.; Duilio, A. Antimicrobial and antibiofilm peptides. Biomolecules 2020, $10,652$. [CrossRef]

28. Costa, E.M.; Silva, S.; Tavaria, F.K.; Pintado, M.M. Insights into chitosan antibiofilm activity against methicillin-resistant Staphylococcus aureus. J. Appl. Microbiol. 2017, 122, 1547-1557. [CrossRef] [PubMed]

29. Gómez-Sequeda, N.; Cáceres, M.; Stashenko, E.E.; Hidalgo, W.; Ortiz, C. Antimicrobial and antibiofilm activities of essential oils against Escherichia coli O157:H7 and methicillin-resistant staphylococcus aureus (MRSA). Antibiotics 2020, 9, 730. [CrossRef]

30. Patel, M.; Ashraf, M.S.; Siddiqui, A.J.; Ashraf, S.A.; Sachidanandan, M.; Snoussi, M.; Adnan, M.; Hadi, S. Profiling and role of bioactive molecules from puntius sophore (Freshwater/brackish fish) skin mucus with its potent antibacterial, antiadhesion, and antibiofilm activities. Biomolecules 2020, 10, 920. [CrossRef] [PubMed]

31. Kasimanickam, R.K.; Ranjan, A.; Asokan, G.V.; Kasimanickam, V.R.; Kastelic, J.P. Prevention and treatment of biofilms by hybridand nanotechnologies. Int. J. Nanomed. 2013, 8, 2809-2819. [CrossRef]

32. Dostert, M.; Belanger, C.R.; Hancock, R.E.W. Design and Assessment of Anti-Biofilm Peptides: Steps Toward Clinical Application. J. Innate Immun. 2019, 11, 193-204. [CrossRef]

33. Ullal, A.J.; Wayne Litaker, R.; Noga, E.J. Antimicrobial peptides derived from hemoglobin are expressed in epithelium of channel catfish (Ictalurus punctatus, Rafinesque). Dev. Comp. Immunol. 2008, 32, 1301-1312. [CrossRef] [PubMed]

34. Zhan, S.; Aweya, J.J.; Wang, F.; Yao, D.; Zhong, M.; Chen, J.; Li, S.; Zhang, Y. Litopenaeus Vannamei Attenuates White Spot Syndrome Virus Replication by Specific Antiviral Peptides Generated from Hemocyanin; Elsevier Ltd.: Amsterdam, The Netherlands, 2019; Volume 91, ISBN 8675486502.

35. Petit, V.W.; Rolland, J.L.; Blond, A.; Cazevieille, C.; Djediat, C.; Peduzzi, J.; Goulard, C.; Bachère, E.; Dupont, J.; DestoumieuxGarzón, D.; et al. A hemocyanin-derived antimicrobial peptide from the penaeid shrimp adopts an alpha-helical structure that specifically permeabilizes fungal membranes. Biochim. Biophys. Acta-Gen. Subj. 2016, 1860, 557-568. [CrossRef]

36. Monteiro, M.L.; Lima, D.B.; de Menezes, R.R.P.P.B.; Sampaio, T.L.; Silva, B.P.; Nunes, J.V.S.; Cavalcanti, M.M.; Morlighem, J.-E.; Martins, A.M.C. Antichagasic effect of hemocyanin derived from antimicrobial peptides of penaeus monodon shrimp. Exp. Parasitol. 2020, 215, 107930. [CrossRef]

37. Zhuang, J.; Coates, C.J.; Zhu, H.; Zhu, P.; Wu, Z.; Xie, L. Identification of candidate antimicrobial peptides derived from abalone hemocyanin. Dev. Comp. Immunol. 2015, 49, 96-102. [CrossRef] [PubMed]

38. Dolashki, A.; Velkova, L.; Daskalova, E.; Zheleva, N.; Topalova, Y.; Atanasov, V.; Voelter, W.; Dolashka, P. Antimicrobial Activities of Different Fractions from Mucus of the Garden Snail Cornu aspersum. Biomedicines 2020, 8, 315. [CrossRef]

39. Ortiz López, C. Design, synthesis, characterization and in vitro evaluation of antimicrobial peptides against pathogenic bacteria resistant to antibiotics. Rev. Acad. Colomb. Cienc. Exact. Fis. Nat. 2019, 43, 614-627. [CrossRef]

40. Cruz, J.; Ortiz, C.; Guzman, F.; Cardenas, C.; Fernandez-Lafuente, R.; Torres, R. Design and activity of novel lactoferrampin analogues against O157:H7 enterohemorrhagic escherichia coli. Biopolymers 2014, 101, 319-328. [CrossRef]

41. Clinical and Laboratory Standards Institute (CLSI). Methods for Dilution Antimicrobial Susceptibility Tests for Bacteria That Grow Aerobically; Approved Standard-Tenth Edition; Clinical and Laboratory Standards Institute: Wayne, PA, USA, 2015; ISBN 1-56238-988-2.

42. Cruz, J.; Flórez, J.; Torres, R.; Urquiza, M.; Gutiérrez, J.A.; Guzmán, F.; Ortiz, C.C. Antimicrobial activity of a new synthetic peptide loaded in polylactic acid or poly(lactic-co-glycolic) acid nanoparticles against Pseudomonas aeruginosa, Escherichia coli O157:H7 and methicillin resistant Staphylococcus aureus (MRSA). Nanotechnology 2017, 28, 135102. [CrossRef] [PubMed]

43. Molhoek, E.M.; van Dijk, A.; Veldhuizen, E.J.A.; Haagsman, H.P.; Bikker, F.J. A cathelicidin-2-derived peptide effectively impairs Staphylococcus epidermidis biofilms. Int. J. Antimicrob. Agents 2011, 37, 476-479. [CrossRef] 